\title{
BIOREMIDIASI TANAH TERKONTAMINASI MINYAK BUMI DENGAN BAKTERI PETROBA DAN BIOSURFAKTAN
}

\author{
Lilis Sugiarti", Fadhilatut Tatqiroh dan Amry Syawalz \\ 1)Fakultas MIPA, UNB Bogor \\ J. KH. Soleh Iskandar Km 4 Cimanggu Bogor \\ Telp. 0252-8340217, 7535605 \\ c-mail : lilis suwamo/ayahoo.co.id
}

\section{ABSTRACT \\ Bioremidiation of Contaminated Petroleum Soil with Petroba Bacteria and Biosurfactans}

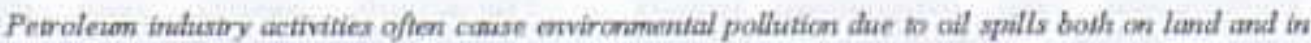
water. Bandang Technology Instinute have isolated severd tnidigenous microba that capable in degrading petroleum named petroba. Petraba it reparted able to degrade fotal petroleum hydrocarbons (TPH) in tite shudge (thick mail) petroleum up to 99 \& wrthn 3 months. Along with the addinton of hiosarfoctants, peroba zapectedable so degrade IPH in a shorter time. The sample used in this study was a perroleum contaninated soth from Prabumalth Sauth Sumatra. The study consisted of three areatments : 1) control (without bacteria anil

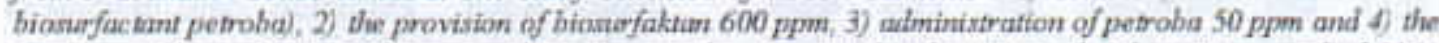
provision of hinmeractants 600 ppm and $50 \mathrm{ppm}$ petraba. Preserved and maintathed xod mointure reached $55 \%$ and given the addition of NPX fertiliter by 01 S per month. The statistical design of this study was canpletly Randomised Destgn (CRD), with 3 roplications. The variables measured were TPH, pH, TPC at beginning and the end of the process (week 10). Initial TPH in soil will do bioremudatioon was 5.27 \% (moderafe contamination). The realis showed that up to 10 weeks on the treatment of bacterial administration go IPH from

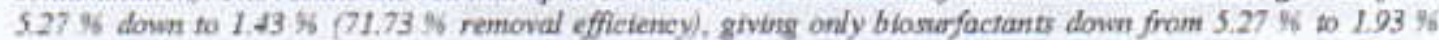
(removil efficiency of 63.3896 ), the addition of hiosurfactant petroba the TPH Ievels dropped from 5.27 .16 to $0.80 \%$, (34.82 36 removal effietency) whereas in the control the IPH down $5.27 \%$ down to 3.09 S fremoval efficiency of 41.37 39. Total bacterial population was inversely related to decreased levels of TPH soil pli of 813 at the intitial stage down to 6 , except for the control of soll $\mathrm{pH}$ was still above 7 .

Keyword : oil, microba, degrade, bicourfactan, bacteria

\section{ABSTRAK}

Aktifitas industri perminyakan seringkali menimbulkan pencemann lingkungan karena adanya trampahan minyak baik di tanah mapun di perainan. ITB talah mengisolasi beberaps isolat milkoba indigenots yang mampu mendegradai petroleum yang diberi nama petroba. Petroba ini dilapcrkan mampu mendegradasi total petroleum hidirckarbon (TPH) pada shudge (lumpur Kental) minyak bumi sampai $98 \%$ dalam waktu 3 bulan. Penambahan petroba bersamaan dengan biosuffaktan dihanapkan mampa mendegradasi TPH dalam waktu yang lebilh singkar. Penelitian ini bertujuan untuk mengetahui efisiensi penurunan kadar TPH pada tanah terkontaminasi minyak buni menggunakan balteri petroba yang dikombinasi dengan biosurfaktan dalam waktu 10 minggu. Sampel yang digunakan dalam penelitian ini adalah tanah terkontaminasi minyak buni yang berasal dan Prabumulih Sumatera Selatan. Penelitian tardiri dan 3 perlakuan yaitu 1) kontrol (tampa bakteri petroba dan biosurfaktan, 2) pemberian biosurfalan $600 \mathrm{ppm}, 3)$ pernberian bakteri potroba 50 ppm dun 4 ) pemberian bicsurfaktan $600 \mathrm{ppm}$ din bakteri petroba $50 \mathrm{ppm}$. Kelembaban tanah dijąa dan dipertahsankan mencapai $55 \%$ dan diberikan penambahan pupuk NPK sebesar 0,1 \% setiap bulan. Rancangan penelitian ini menggunanakan RAL, dengan 3 kali ulanxan. Variabel yang diamati adalah TPH, pH,TPC awal dan alhir proses (sampai minggu bo-10). TPH awal pada taruh yang akan dilakukan bioremidiasi adalah $5,27 \%$ (pencemarun tingkat sedang) denqan $\mathrm{pH} 8,13$. Hasil penelitian menuniukkan bahwa sampai mingen ke-10 pada periakan pemberian baitteri petroba sajaTPH dari $5,27 \%$ turun menjadi $1,43 \%$ (efisiensi pemunuman $71,73 \%$ ), pornberian biosurfaktan saja TPH dati $5,27 \%$ turun meniadi $1,93 \%$ (efisiensi penurumn $63,38 \%$ ), pernambahan petroba dan bicsurfaktan kadar TPH dari $5,27 \%$ turun menjadi $0,80 \%$, (efisiensi penurunan $84,82 \%$ ) sedangkan pada kontrol TPH dari $5,27 \%$ turun menjadi $3,09 \%$ (etisienst penurunan $41,37 \%$ ). Jumlah populasi bakteri berbanding terbalik dengan permanan kadar TPH pH tamah dari 8,13 pada tahap awal tumm sampai 6 kecuali pada kontrol pH tumah masih diatas 7.

Kata kand : minyak, mikroba, degradasi, biosufabkan, bakkeri 


\section{PENDAHULUAN}

Aktifitas industri perminyakan seringkali menghasilkan limbah berupa tumpahan minyak baik di tanah maupun di perairan (Udiharto, 1996). Penanganan limbah yang tidak tepat dapat menyebabkan pencemaran lingkungan dan berbahaya bagi makhluk hidup (Herdiyantoro, 2005). Alternatif lain yang dapat digunakan dalam penanggulangan pencemaran minyak bumi adalah teknologi bioremediasi yaitu penggunaan bakteri yang dalam aktivitasnya mampu memanfaatkan hidrokarbon minyak bumi sebagai sumber karbon dan encrgi kemudian mengubahnya menjadi $\mathrm{CO}_{2}$. $\mathrm{H}_{2} \mathrm{O}$ dan biomassa sel. ITB telah memproduksi "petroba" yaitu suatu biakan mikroba yang mengandung puluhan jenis isolat mikroba indigenous yang mampu mendegradasi petrolium. Hasil pengujian di laboratorium maupun di lapangan dilaporkan bahwa petroba yang diujikan pada sludge (lumpur kental) minyak bumi dapat mendegradasi total petroleum hidrokarbon (TPH) sampai $98 \%$ dalam waktu 3 bulan. Karakteristik minyak bumi yang tidak larut dalam air dan terjerap pada partikel tanah dapat mengurangi bioavailabilitas bakteri dalam memanfaatkan hidrokarbon schingga menjadi faktor pembatas laju biodegradasi. $\mathrm{Hal}$ ini disebabkan karena aktivitas bakteri dalam biodegradasi beriangsung pada antar muka air-minyak dalam larutan tanah (Wick et al., 2001). Salah satu cara untuk mengatasi hal tersebut adalah dengan mengaplikasikan surfaktan, yaitu suatu molekul yang mempunyai bagian hidrofilik. dan hidrofobik yang mampu menurunkan tegangan antar muka air dan minyak (Tiehm \& Stieber, 2001). Penggunaan petroba atau biosurfaktan saja belum memberikan hasil yang memuaskan terutama dalam segi waktu dalam menurunkan kadar TPH yang terdapat pada tanah yang terkontaminasi minyak bumi. Penclitian ini bertujuan untukmengetahui efisiensi penurunan kadar TPH pada tanah terkontaminasi minyak bumi menggunakan bakteri petroba yang dikombinasi dengan biosurfaktan dalam waktu 10 minggu.

\section{BAHANDAN METODE}

\section{Bahan dan Alat}

Sampel yang digunakan dalam penelitian ini adalah tanah terkontaminasi minyak bumi yang berasal dari Prabumulih Sumatera Selatan, berasal dari kebocoran pipa-pipa di Pertamina EP(Eksplorasi) Prabumulih, bakteri yang digunakan adalah bakteri indigenous yang diperoleh dari Laboratorium IIB dengan nama petroba dalam bentuk padatan. biosurfaktan, pupuk NPK, media PCA, dan pepton water. Peralatan yang digunakan adalah bak plastik, sprayer, waterbath merek MEMMERT, kondensor, oven merek MEMMERT, soil tester model DM5 , inkubator, cawan petri, coloni counter dan pengaduk.

\section{Metode Penelitian}

Rancangan penelitian yang digunakan adalah rancangan acak lengkap (RAL) dengan 4 perlakuan, yaitu: tanah terkontaminasi 1) ditambahkan petroba 50 $\mathrm{ppm}_{2}$ 2) ditambahkan biosurfaktan 600 $\mathrm{ppm}, 3)$ ditambahkan bakteri petroba 50 ppm dan biosurfaktan $600 \mathrm{ppm}$ dan 4) kontrol (tanpa penambahan biosurfaktan dan petroba) dengan 3 kali ulangan. Variabel yang diamati adalah TPH, pH,TPC awal dan akhir proses (minggu $\mathrm{ke}-10$ ). Kondisi lingkungan yaitu kelembaban yang dikontrol setiap hari (dengan mempertahankan kondisi kelembaban $55 \%$ ) dipantau menggunakan soil tester. Tanah dipupuk sebulan sekali dengan pupuk NPK $0,1 \%$. Penurunan TPH dan $\mathrm{pH}$ dilihat secara berkala 2 minggu sekali. Penetapan kadar TPH menggunakan metode ektralssi soklet.

\section{Cara Kerja}

Tanah terkontaminasi minyak bumi dihaluskan dan dihomogenkan dengan cara diaduk, kemudian ditimbang $1 \mathrm{~kg}$ dimasukan kedalam bak plastik. 
Bakteri petroba 50 ppm ditambahkan kedalam tanah terkontaminasi dan ditebar secara merata dan diaduk. Penambahan petroba dilakukan setiap bulan. Untuk perlakuan penambahan biosurfkatan 6000 ppm kedalam tanah dilakukan dengan menggunakan syiringe. Penambahan biosurfaktan dilakukan setiap bulan. Penambahan nutrisi dilakukan pada semua perlakuan dengan menggunakan pupuk NPK dengan dosis $0.1 \%$, Penambahan pupuk dilakukan setiap bulan. Penyiraman dan pengadukan dilakukan setiap hari dengan rata-rata kelembaban $55 \%$ dengan menggunakan soil tester, Pengamatan yang dilakukan meliputi $\mathrm{pH}$, kelembaban, TPH dan TPC.

\section{Pengukuran TPH}

Sampel tanah kering ditimbang sebanyak 2 gram dan dimasukkan kedalam selongsong, kemudian selongsong ditutup dengan kapas. Labu didih ditimbang. Selongsong dan labu didih ditempatkan pada peralatan ekstraksi. Sampel diekstraksi selama 7 jam menggunakan pelarut hexan: aceton 1:1 pada suhu $95^{\circ} \mathrm{C}$. Hasil ekstraksi di dalam labu didih dimasukkan kedalam oven dengan suhu $90^{\circ} \mathrm{C}$, kemudian didinginkan dan ditimbang sampai diperoleh bobot tetap. Hasil ckstraksi kemudian dilarutkan dengan heksan, disaring menggunakan silika dan ditampung menggunakan beaker glass yang sudah diketahui berat keringnya. Hasil yang sudah disaring dioven dengan suhu $60-70^{\circ} \mathrm{C}$, kemudian didinginkan dan ditimbang. Pengeringan sampel diulangi sampai diperoleh bobot tetap. Pengukuran TPH dilakukan setiap 2 minggu sckali.

$\% \mathrm{TPH}=\frac{(\mathrm{MI}-\mathrm{M} 0)}{\mathrm{M} 2} \times 100 \%$

Keterangan :

$\mathrm{M0}=$ Bobot beaker kosong $(\mathrm{g})$

$\mathrm{M1}=$ Bobot beaker berisi ekstrak sampel

$M 2$ = bobot tanah $(\mathrm{g})$

\section{Analisis TPC}

Sampel ditimbang secara aseptik sebanyak $10 \mathrm{~g}$ kedalam erlenmayer steril, ditambahkan $90 \mathrm{ml}$ pepton water, dikocok sampai tercampur homogen (Sebagai pengenceran $10^{-1}$ ). 2 tabung reaksi steril disiapkan yang masing - masing telah berisi $9 \mathrm{ml}$ pepton water untuk pengenceran $10^{-2}$ dan $10^{-3}$. Satu $\mathrm{ml}$ larutan suspensi pengenceran $10^{-4}$ dipipet, dimasukkan kedalam tabung reaksi yang telah berisi $9 \mathrm{ml}$ pepton water dan dihomogenisasi (pengenceran $10^{-2}$ ). Satu $\mathrm{ml}$ larutan suspensi pengenceran $10^{-2}$ dipipet dimasukkan kedalam tabung reaksi yang telah berisi $9 \mathrm{ml}$ pepton water dan dihomogenisasi (pengenceran $10^{-3)}$ Masing-masing pengenceran dipipet $1 \mathrm{ml}$ dan dimasukkan kedalam cawan petri stcril, ditambahkan masing-masing 15-20 $\mathrm{ml}$ media PCA. Media dicampur dengan cara menggoyang cawan secara merata, didiamkan hingga memadat lalu ditutup. Sebagai kontrol dimasukan $1 \mathrm{ml}$ pepton water kedalam cawan petri steril, ditambahkan 15-20 ml media PCA digoyang cawan agar merata lalu didiamkan hingga memadat (sebagai kontrol terhadap larutan pengencer). Sebagai konntrol media, cawan hanya berisi media PCA saja. Semua cawan diinkubasi pada suhu $30^{\circ} \mathrm{C}-35^{\circ} \mathrm{C}$ selam $48 \mathrm{jam}$. Jumlah koloni bakteri diamati dan dihitung menggunakan colony Counter.

Pengukuran pH Tamah (SNI 06-6989.112004)

Sampel tanah kering udara ditimbang $\neq 10$ gram, ditambahkan $25 \mathrm{ml}$ air suling latu dikocok selama 30 menit dengan pengaduk magnetik. $\mathrm{pH}$ larutan kemudian diukur dengan $\mathrm{pH}$ meter yang sebelumnya dikalibrasi.

\section{HASIL DAN PEMBAHASAN}

$\mathrm{pH}$

Hasil pengamatan $\mathrm{pH}$ pada penelitian ini sampai minggu kesepuluh 
pada berbagai perlakuan dapat dilihat pada gambar 1.

$\mathrm{pH}$ merupakan salah satu faktor yang penting dalam penurunan biodegradasi TPH. Pada gambar 1 terlihat pada semua perlakuan terjadi penurunan $\mathrm{pH}$ dari sekitar 8 menjadi 7-6. Penurunan $\mathrm{pH}$ terbesar terlihat pada perlakuan 3 yaitu penambahan kombinasi petroba dan biosurfaktan, dilanjutkan perlakuan 1 (penambahan petroba), pelakuan 2 (penambahan biosurfaltan) dan terakhir pada kontrol.

Pada perlakuan penambahan kombinasi petroba dan biosurfaktan selama 10 minggu terjadi penurunan nilai $\mathrm{pH} 8,13$ menjadi 6,02. Adanya penambahan kombinasi bakteri petroba dan biosurfaktan menyebabkan penurunan nilai $\mathrm{pH}$ menjadi lebih tinggi dibandingkan dengan ketiga perlakuan diatas. Adanya penurunan nilai $\mathrm{pH}$ menunjukan adanya aktivitas mikroorganisme, membentuk metabolitmetabolit asam. Mikroorganisme akan mengkonsumsi hidrokarbon sebagai sumber karbon untuk menghasilkan energi bagi kelangsungan hidupnya dan akan mengeluarkan metabolit-metabolit kedalam media, yaitu dapat berupa gas $\mathrm{CO}_{2}, \mathrm{H}_{2} \mathrm{O}$, biomassa, dsb. Gas $\mathrm{CO}_{2}$ yang dikeluarkan akan berekasi dengan $\mathrm{H}_{2} \mathrm{O}$ dan menghasilkan asam ( $\left.\mathrm{H}^{+}\right)$yang dapat menurunkan pH (Styani, 2008).

$\mathrm{CO}_{2}+\mathrm{H}_{2} \mathrm{O} \rightarrow \mathrm{H}_{2} \mathrm{CO}_{3} \rightarrow \mathrm{H}^{+}+\mathrm{HCO}_{3}^{-}$

Oleh karena itu, selama proses biorcmediasi berlangsung, akan terjadi penurunan penurunan $\mathrm{pH}$. Besarnya penurunan nilai $\mathrm{pH}$ yang dihasilkan olch keempat perlakuan tersebut berbeda-beda tergantung pada besamya presentase biodegradasi dan bakteri yang mendegradasinya. Semakin tinggi aktivitas bakteri pendegradasi hidrokarbon maka semakin tinggi pula jumlah asam - asam organik yang dihasilkan dan mengakibatkan semakin besar penurunan pH (Styani, 2008).

Kebanyakan bakteri tumbuh pada $\mathrm{pH}$ netral atau sedikit alkali. $\mathrm{pH}$ berpengaruh pada fungsi seluler mikroorganisme, transport membrane dan keseimbangan reaksi (Sugoro, 2002). $\mathrm{pH}$ larutan meneerminkan kandungan yang terlarut didalamnya. Degradasi hidrokarbon lebih cepat dilakukan pada kondisi diatas 7 dibandingkan $\mathrm{pH}$ dibawah 5.

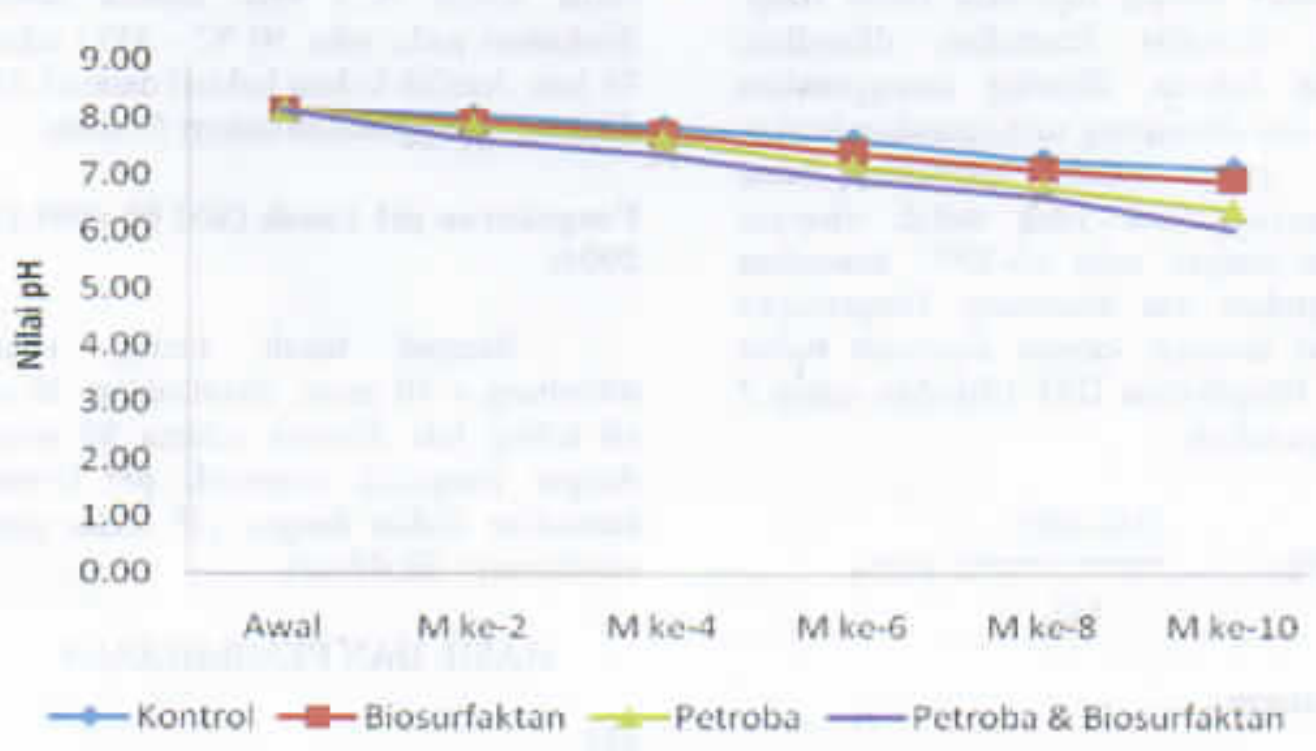

Gambar 1. Grafik Penurunan $\mathrm{pH}$ Tanah Terkontaminasi Pada Berbagai Perlakuan sampai Minggu ke 10 


\section{Kadar TPH}

Kadar TPH diamati setiap 2 minggu sekali sampai minggu $k e-10$. Analisis kadar TPH ini dilakukan untuk melihat kemampuan degradasi hidrokarbon. Hasil analisis kadar TPH pada ke empat perlakuan yang dicobakan sampai minggu ke-10 dapat dilihat pada Gambar 2

Kadar TPH awal pada tanah terkontaminasi minyak adalah $5,27 \%$ Menurut Keputusan Menteri Negara No 128 tahun 2003 menyatakan bahwa konsentrasi maksimum TPH awal sebelum proses pengolahan biologis tidak boleh lebih dari $15 \%$. Kisaran nilai TPH awal

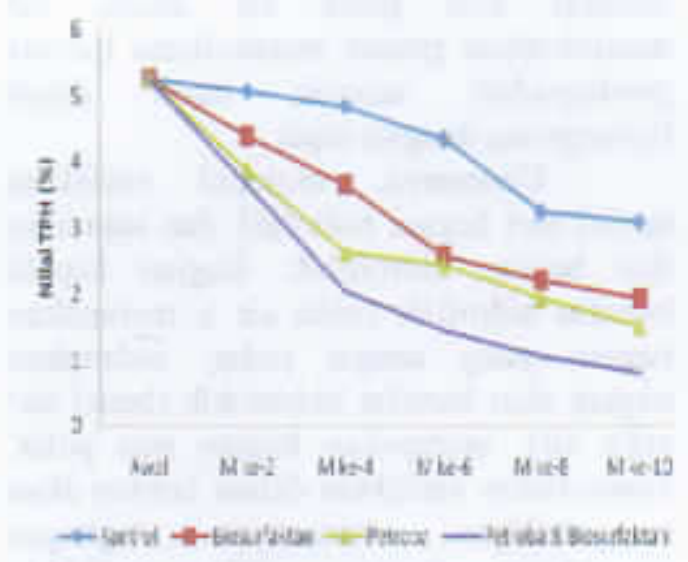

(a) pada degradasi minyak bumi secara hayati adalah $2-10 \%$. Kondisi ini merupakan kondisi yang tidak terialu toksik untuk aktivitas bakteri yang menjadi persyaratan teknis pada proses bioremediasi (Jamilah.,2005).

Pada Gambar 2, menunjukan bahwa pada semua perlakuan terjadi penurunan TPH dalam kurun waktu 10 minggu pengamatan. Perbedaan hasil dalam proses biodegradasi dapat disebabkan karena adanya aktivitas mikroflora yang terkandung dalam lumpur berminyak itu sendiri yang turut berperan dalam mendegradasi hidrokarbon, maupun perbedasan komposisi dan struktur kimia lumpur berminyak (Syafrizal et al.,2010).

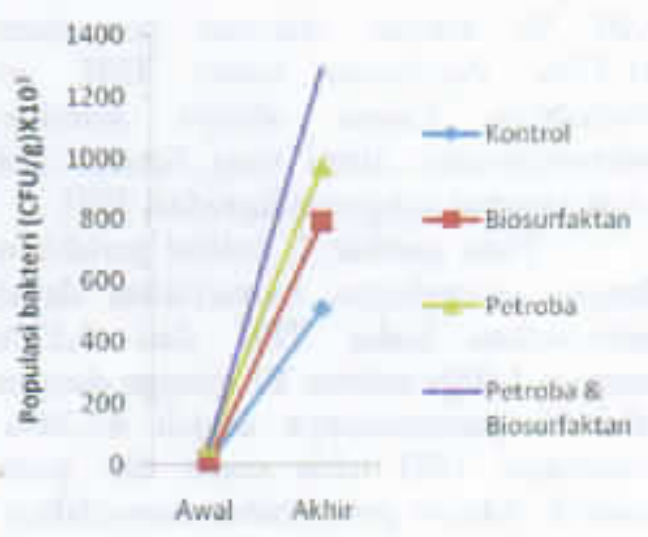

(b)

Gambar 2 (a) Grafik Penurunan Kadar TPH-Tanah Terkontaminasi Minyak Bumi pada Berbagai Perlakuan sampai minggu ke-10 dan (b) populasi bakteri awal dan akhir proses.

\section{Kontrol}

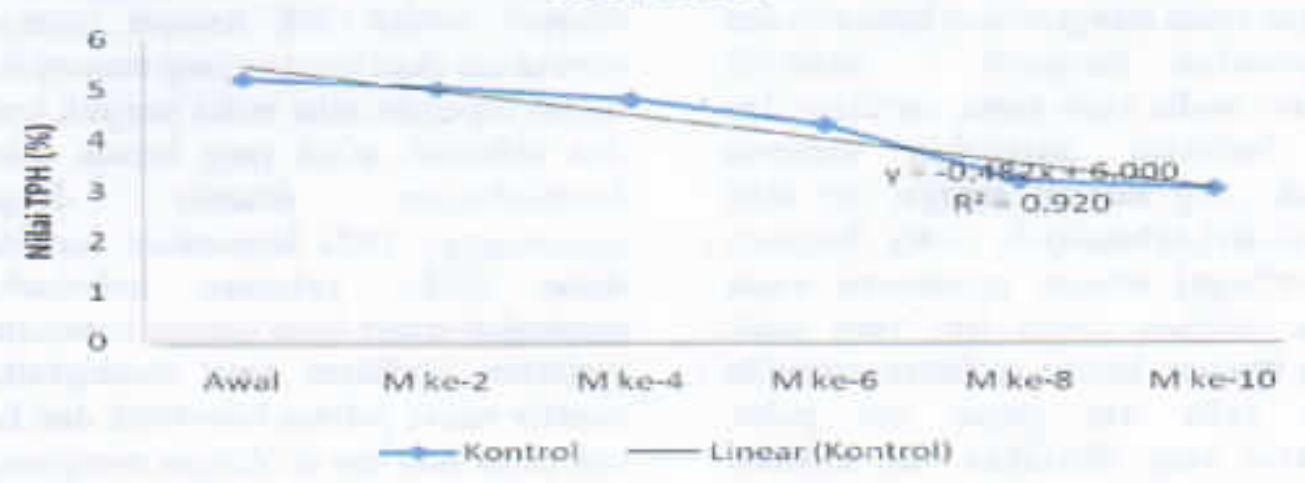

Gambar 3. Grafik Penurunan Kadar TPH Tanah Terkontaminasi Minyak Bumi Pada Perlakuan Kontrol sampai minggu ke-10 


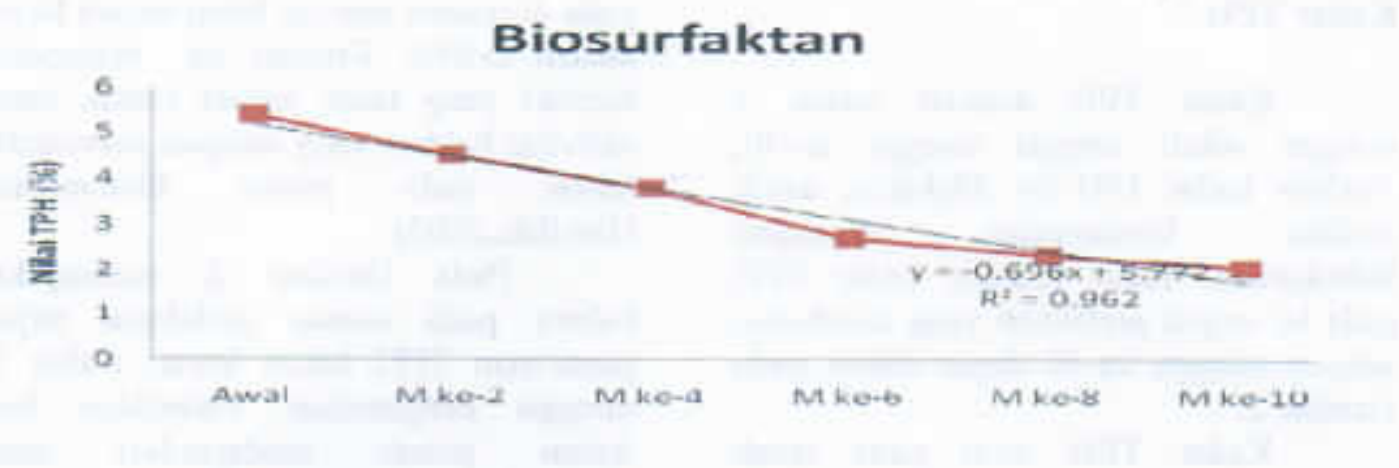

Gambar 4. Grafik Penurunan Kadar TPH Tanah Terkontaminasi Minyak Bumi Pada Perlakuan Penambahan Biosurfaktan sampai minggu ke-10

Pada gambar 3 terlihat penurunan TPH pada kontrol dari $5,27 \%$ menjadi $3,09 \%$ dengan efisiensi penurunan 41,37\% Penurunan kadar TPH ini disebabkan karena adanya aktivitas mikroorganisme alami yang berasal dari tanah tersebut yang mendegradasi TPH.

Pada gambar 4 , teriihat perlakuan dengan penambahan biosurfaktan dapat menurunkan kadar TPH dari $5,27 \%$ menjadi $1,93 \%$ selama 10 minggu dengan efisiensi penurunannya adalah $63,38 \%$ Penurunan TPH lebih eepat dari pada kontrol. Adanya penambahan biosurfaktan memperopat kelarutan minyak dalam air sehingga mempermudah bakteri yang ada dalam tanah tersebut dalam mendegradasi hidrokarbon.

Menurut Udiharto et al., (1995) selama proses biodegradasi berlangsung bakteri memakan hidrokarbon dari minyak buangan untuk menghasillkan biomassa dan mengeluarkan metabolit - metabolit kedalam modia yaitu asam, surfaktan dan gas. Surfaktan merupakan senyawa organik yang bersifat scbagai zat aktif permukaan (Akhmaisyah, 2006). Senyawa ini berfungsi sebagai pendispersi suatu cairan kedalam cairan lain yang tidak saling campur, karena surfaktan memiliki gugus polar dan gugus non polarSurfaktan yang dihasilkan olch mikroba yang ada dalam tanah itu sendiri tidak mencukupi sehingga perlu penambahan surfaktan kedalam suatu campuran minyak dan air. Hal ini dimaksudkan agar substrat (minyak) lebih larut dalam air. Larutnya substrat non polar ini dalam air menyebabkan proses metabolisme bakteri pendegradasi minyak bumi dapat berlangsung dengan cepat.

Umumnya, molekul surfaktan terdiri dari bagian hidrofilik dan satu atau dua bagian hidrofobik. Bagian kepala bersifat hidrofilik (suka air), merupakan bagian yang sangat polar, sedangkan bagian ekor bersifat hidrofobik (benci air/ suka air), merupakan bagian non polar. Penambahan surfaktan dalam larutan akan menyebabkan turunnya tegangan pernukaan larutan. Bila surfaktan ditambahkan melebihi konsentrasi tertentu maka surfaktan akan mengagregasi membentuk misel. Konsentrasi terbentuknya misel ini disebut Critical Micelle Concentration (CMC). Tegangan permukaan akan menurun hingga $\mathrm{CMC}$ tercapai. Setelah CMC tercapai, tegangan permukaan akan konstan yang menunjukan bahwa tegangan antar muka menjadi jenuh dan terbentuk misel yang berada dalam kesetimbangan dinamis dengan monomemya. Pada konsentrasi surfaktan diatas CMC, kelarutan hidrokabon meningkat secara linier dengan konsentrasi surfaktan. Surfaktan dapat meningkatkan transfer massa polutan hidrofobik dari fase cair padat atau non air dengan mengurangi tegangan permukaan antar muka dengan mengunpulkan senyawa hidrofobik kedalam misel (Jing \& Bing., 2009). 


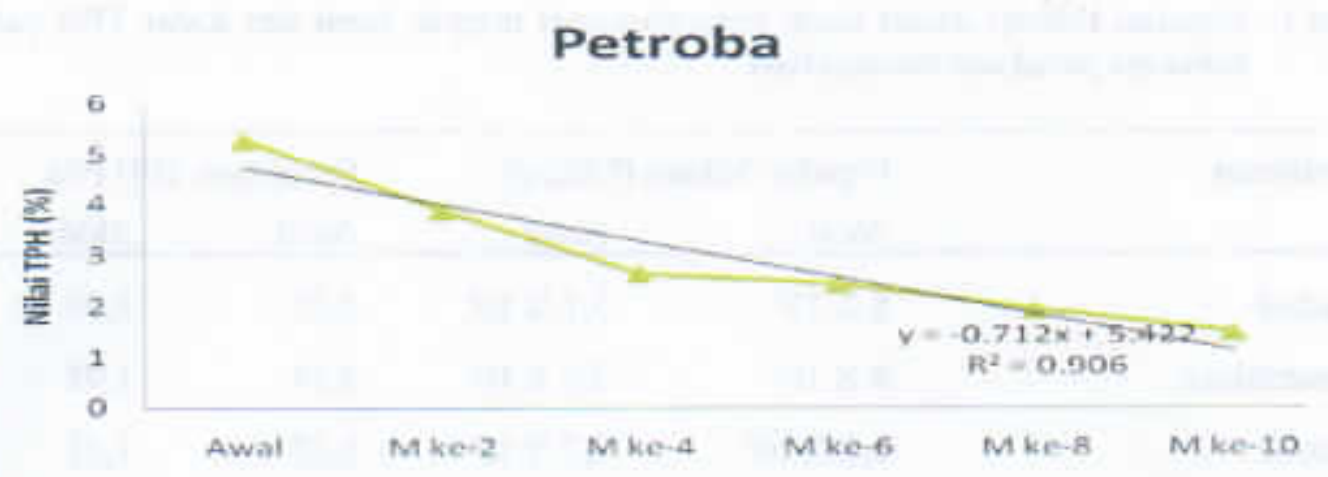

Gambar 7. Grafik Penurunan Kadar TPH Tanah Terkontaminasi Minyak Bumi Pada Perlakuan Penambahan Petroba sampai minggu ke-10

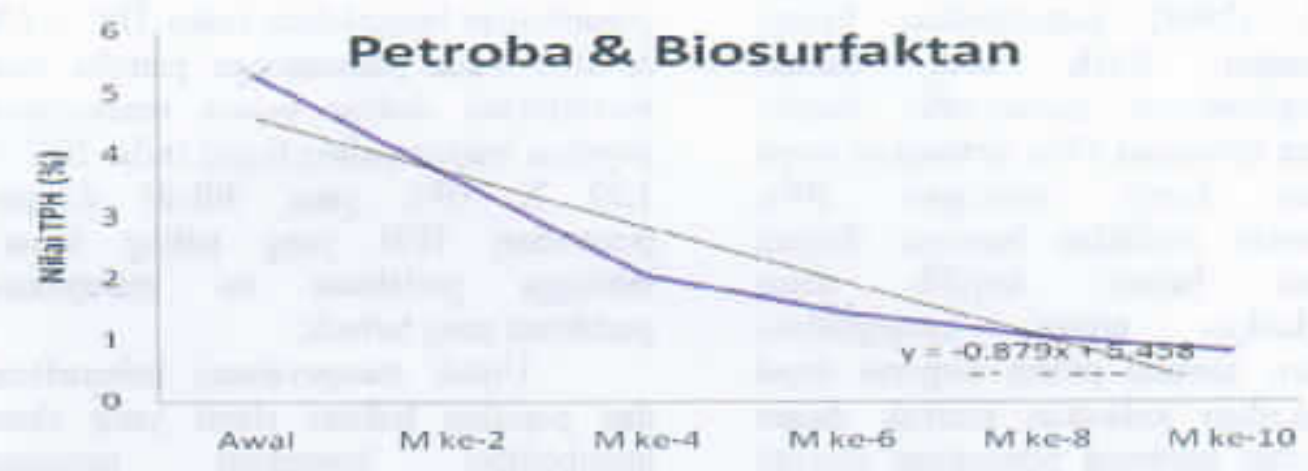

Gambar 8. Grafik Penurunan Kadar IPH Tanah Terkontaminasi Minyak Bumi Pada Perlakuan Penambahan Petroba dan Biosurfaktan sampai minggu ke-10

Pada gambar 7 terlihat bahwa pada perlakuan penambahan petroba sclama 10 minggu menunjukan penurunan TPH dengan efisiensi penurunan sebesar 71,73 $\%$ (dari 5,27\% menjadi 1,49\%). Adanya penambahan bakteri petroba lebih mempercepat penurunan kadar TPH dibandingkan kontrol maupun penambahan biosurfaktan. Semakin banyak jumlah bakteri terutama bakteri terpilih semakin mempereepat degradasi hidrokarbon.

Pada perlakuan ini, penambahan sel mikroba akan membanyak interaksi dengan partikel hidrokarbon yang lebih kecil dari pada sel. Hidrokarbon dapat teremulsi dan tersolubilisasi dengan adanya biosurfaktan yang dilepaskan oleh bakteri kedalam medium.
Pada gambar 8 terlihat bahwa penambahan kombinasi bakteri petroba dan biosurfaktan dapat menurunkan kadar TPH scbesar $84,82 \%$ (dari TPH $5,27 \%$ $0,80 \%$ ) dalam waktu 10 minggu. Nilai ini tclah meneapai standar yang ditetapkan olch Menteri Negara Lingkungan Hidup No 128 tahun 2003 yang menyatakan bahwa nilai akhir hasil olahan suatu lahan tercemar minyak bumi mulai bisa dimanfaatkan kembali jika kadar TPH dalam tanah tersebut mencapai $1 \%$ atau kurang dari $1 \%$ Konsorsium bakteri terpilih dan biosurfaktan mampu menurunkan kadar TPH sampai dibawah $1 \%$ dengan waktu yang lebih singkat dibandingkan dengan ketiga perlakuan. 
Tabel 1. Populasi Bakteri dalam tanah terkontaminasi minyak bumi dan kadar TPH pada beberapa perlakuan bioremidiasi

\begin{tabular}{|c|c|c|c|c|}
\hline \multirow[t]{2}{*}{ Perlakuan } & \multicolumn{2}{|c|}{ Populasi bakteri (CFU/g) } & \multicolumn{2}{|c|}{ Penurunan TPH (\%) } \\
\hline & Awal & Akhir & Awal & Akhir \\
\hline Kontrol & $8 \times 10^{3}$ & $5,1 \times 10^{5}$ & 5,27 & 3,09 \\
\hline Biosurfaktan & $8 \times 10^{3}$ & $7,9 \times 10^{5}$ & 5,27 & 1,93 \\
\hline Petroba & $5,8 \times 10^{4}$ & $9,7 \times 10^{5}$ & 5,27 & 1,43 \\
\hline Petroba \& Biosurfaldam & $5,8 \times 10^{4}$ & $1,29 \times 10^{6}$ & 5,27 & 0,80 \\
\hline
\end{tabular}

Penambahan surfaktan dapat meningkatkan laju biodegradasi. Boonchan et al., (1998) menyebutkan bahwa biodegradasi PAHs olch bakteri Stenotrophomonas maitophifia dengan surfaktan meneapai $67 \%$, sedangkan tanpa surfaktan hanya mencapai $30 \%$. Penggunaan surfaktan bersama dengan inokulasi bakteri terpilih dapat meningkatkan proses biodegradasi. Surfaktan, melalui proses disperse dapat meningkatkan kelarutan minyak dalam fase cairan sehingga permukaan minyak yang dapat didegradasi oleh bakteri bertambah (Sabagh \& Atta,1999).

\section{Populasi Bakteri}

Hasil perhitungan bakteri awal dan akhir proses pada berbagai perlakuan dapat dilihat di Tabel L. Pada tabel 1 terjadi peningkatan populasi pada semua perlakuan yang menunjukan bahwa bakteri dapat tumbuh dengan baik selama proses degradasi berlangsung.

Pada penambahan biosurfaktan populasi bakteri lebih tinggi dibandingkan kontrol yang menunjukan bahwa dengan adanya penambahan biosurfaktan, tegangan permukaan menjadi turun sehingga hidrokarbon lebih mudah didegradasi oleh bakteri dan sebagai sumber nutrisi. Adanya nutrisi yang meneukupi akan mampu menahan laju kematian.

Pada perlakuan penambahan bakteri petroba, populasi bakteri (nilai $\mathrm{TPC}=9,7 \times 10^{5}$ ) pada akhir proses (minggu $k e-10$ ) lebih tinggi dari pada populasi bakteri pada perlakuan penambahan biosurfaktan (nilai TPC $=7,9$ $X 10^{5}$ ). Pada penambahan petroba dan biosurfaktan diakhir proses mempunyai populasi bakteri paling tinggi (nilai TPC = $\left.1,29 \times 10^{\circ}\right)$, yang diikuti dengan penurunan TPH yang paling besar, schingga perlakuan ini merupakan periakuan yang terbaik.

Untuk mengevaluasi keberadaan dan populasi bakteri alami yang akan memberikan kontribusi terhadap penurunan minyak bumi, bioremediasi dengan metode landfarming, akan efektif jika nilai TPC minimum $10^{\circ} \mathrm{CFU} /$ gram atau debih. Jika nilai TPC kurang dari $10^{\circ}$ CFU/gram, tidak direkomendasikan untuk dilakukan bioremediasi karena hal itu menunjukkan adanya konsentrasi racun organik atau anorganik (misalnya, scnyawa logam) yang meracuni bakteri terscbut. (EPA GUIDELINES, 2005).

\section{KESIMPULAN DAN SARAN}

\section{KESIMPULAN}

Berdasarkan hasil penelitian selama sepuluh minggu, nilai akhir kadar TPH pada kontrol adalah $3,09 \%$, pada penambahan biosurfaktan $1,93 \%$, penambahan petroba adalah $1,43 \%$ dan pada penambahan kombinasi petroba dan biosurfaktan $0,80 \%$ Kombinasi petroba dan biosurfaktan memberikan hasil yang optimum dibandingkan ketiga perlakuan yang lain. 
SARAN

Untuk penelitian lebih lanjut sebaiknya dilakukan variasi penggunaan biosurfaktan dalam berbagai komposisi.

\section{DAFTAR PUSTAKA}

Akhmaisyah. 2006. Potensi Streptomyces sp. Isolat Lokal dalam Mendegradasi Limbah Minyak Bumi. IPI3. Bogor.

Boonchan S, MI Britz \& GA Stanley. 1998. Surfactan enhanced biodegradation of high moleculer weight polycyclic aromatic hydrocarbons Stenotrophomonas maltophilia. Bioetechnol and bicengineering. $59: 482-494$.

EPA GUIDELINES. 2005. Soil Bioremediation. Australia.

Herdiyantoro D. 2005. Biodegradasi Hidrokarbon Mimyak Bumi Baclins sp. Galur ICBB 7859 dan ICBB 7865 dari Ekosistem Air Hitam Kalimantan Tengah dengan Penambahan Surfaktan. IPB. Bogor.

Jamilah. 2005. Potensi Baktert Pendegradasi Hidrakarbon Minyak Bumt pada Tanah Tenkontaminasi Minyak Bumit dengan Penambahan Surfaktan. Falultas MIPA. IPB. Bogor.

Jing Ling Li \& Bing Hung Chen. 2009. Surfactan mediated Biodegradation of Polycyclic Aromatic Hidrokarbon. Materials.2, 76-94.

Sabagh A \& AM Atta. 1999, Water Based Non-Ionic Polymeric Surfactants as oil Spill Dispersants. I Chem Technol Biotechnol. 74 : 1075 1081
Syafrizal, DS Rani \& SA Rahayu.2010. Pemanfautan Surfaktan dalam Pengolahan Limbah Berminyak secara Bioproses. Prosiding Seminar Nasional Teknik Kimia Kejuangan. Yogyakarta.

Sugoro, 1. 2002. Bioremediasi 'Sludge' Limbah Minyak Bum Tercemar dengan Teknik Landfarming dalam Skala Laboratorium. IIB : Bandung.

SNI 06-6989. 11-2004. Cara Uji Derajat Keasaman Menggunakan pH Meter. BSN

Styani E.2008. Bioremediasi Tamah Terkontaminasi Minyak Bumi Menggunakan Bakteri Bacillius sp dan Pseudomonas sp. WARTA $A K A B$. Akademi Kimia Analisis Bogor. Bogor. No $19 \mathrm{Hlm} 47-58$.

Tiehm A \& Stieber M. 2001. Strategies to improve PAH btoanabtlity: addition of surfactans, ozonation and application of ultrasound. Didalam Stegmann R, Brumer G, Calmano W, Matz G, editors. Treatment of contaminated Soil. Berlin, Heidelberg, New York, Barcelona, Hongkong. London, Milan, Paris, Singapore, Springer : Tokyo. Him $299-323$.

Udiharto M.1996. Bioremediasi minyak bumi. Prosiding Pelatihan dan Lokakarya. Peranan Bioremediasi dalam Pengelolaan Lingkwngan. Cibinong. hlm 24-39.

Wick LY, D Springatel \& H Harms. 2001. Bacterial strategis to improve the bioavallability of hydrophobic organte pollutans. Tokyo. Hlm $204-217$. 